\title{
Las santitas del barrio. "Beatas" laicas y religiosidad cotidiana en la ciudad de México en el siglo XVII
}

\author{
Antonio Rubial García \\ Universidad Nacional Autónoma de México
}

\begin{abstract}
El estudio del caso inquisitorial de las hermanas Romero (unas falsas místicas que vivieron en la ciudad de México a mediados del siglo XVII) sirve de ventana para aproximarse a varios temas relacionados con la oralidad y sus prácticas comunicativas, la transmisión de valores religiosos y su control por parte de los laicos y la recepción de la literatura hagiográfica en los medios populares. Las prácticas cotidianas de la religión católica en las ciudades que formaban el imperio español pueden ser entendidas en un contexto en el que lo milagroso vivía el tránsito entre la credulidad y el escepticismo. El caso de las hermanas Romero es uno de los numerosos casos de beatas embaucadoras y ermitaños que se dieron en los dos virreinatos y que muestran que, tanto los arrebatos místicos como el culto a las reliquias y la manipulación de lo sagrado no fue exclusivo de los sectores eclesiásticos y monacales y que los laicos hicieron uso de tales instrumentos de una manera amplia y con gran aceptación por parte de la sociedad, incluido el aparato eclesiástico.
\end{abstract}

El concilio de Trento marcó un profundo cambio en la relación entre las prácticas religiosas de los laicos y los controles eclesiásticos sobre ellas. A la activa participación de esos sectores y a su creciente autonomía (hecho que se venía dando en Occidente desde el siglo XIII), se pretendió enfrentar una mayor sujeción y el ejercicio de unas prácticas dirigidas por los clérigos y ejercidas en los espacios sacralizados por la Iglesia. Con todo, fue imposible detener un impulso que daba a los laicos (la mayoría de los fieles cristianos) y al ámbito doméstico una mayor presencia religiosa y fue difícil limitar el fenómeno de apropiación de la dirección de tales prácticas por parte de miembros de esos sectores.

$\mathrm{Al}$ igual que acontecía en Europa, en Nueva España numerosos hombres y mujeres que no habían hecho votos religiosos tuvieron una activa actuación en la promoción de prácticas religiosas de clérigos y laicos. Una cantidad no determinada de ellos actuaron en las ciudades novohispanas con bastante libertad y, aunque muchos fueron llevados ante el tribunal del Santo Oficio (cuya acción judicial nos permite ahora estudiarlos) desarrollaron sus actividades religiosas durante años, antes de ser consignados como sospechosos de herejía o de fingimiento místico. Las mujeres, sobre todo, se encontraban en una posición ambigua pues, por su género, se les 
consideraba seres que debían estar subordinados a los varones pero, por otro lado, se les atribuían capacidades especiales para comunicarse directamente con Dios. Algunas de ellas, como la esclava hindú Catalina de San Juan, fueron consideradas santas y varios clérigos escribieron sus biografías; otras, como María de Poblete, practicaron sus devociones y desarrollaron sus milagros apoyadas por sus parientes clérigos y fueron muy bien aceptadas, e incluso veneradas, hasta el momento de su muerte; hubo finalmente otras (cuarenta y cinco en los siglos XVII y XVIII) que cayeron en las cárceles inquisitoriales acusadas de fingimiento místico o de alumbradismo.

El presente artículo tiene como finalidad mostrar el desarrollo de las prácticas femeninas de este último grupo a partir de un estudio de caso: el de las hermanas Romero. Sus procesos inquisitoriales han sido objeto de varias menciones en trabajos especializados sobre el Santo Oficio, como los de Solange Alberro y Nora Jaffary, pero considero que su impacto en la vida cotidiana de la ciudad de México no ha sido aún suficientemente estudiado. ${ }^{1}$

\section{¿Una familia ejemplar?}

Juan Romero Zapata, criollo y barbero de oficio que tenía un tendajón en el barrio de San Pablo en Puebla, decidió trasladarse por el año de 1626 desde su lugar de origen hacia Cholula, para buscar una forma de vida que le permitiera mantener más desahogadamente a una familia que iba en aumento. Su mujer, Leonor Márquez de Amarilla (que procedía de un importante linaje poblano venido a menos), le había dado dos hijas gemelas (Josefa y María) y un varón (Lucas), a quienes se unieron Nicolasa y Juan, nacidos en Cholula. ${ }^{2}$ A la familia se agregó también por ese tiempo

1 Solange Alberro, en su artículo "La licencia vestida de santidad: Teresa de Jesús, falsa beata del siglo XVII", en Sergio Ortega ed., De la santidad a la perversión, México, 1985, págs. 219-238, ha tratado el caso de una de las hermanas pero sin mencionar a las otras. En su libro Inquisición y sociedad en México, 1571-1700, México, 1988, págs. 493 y ss. vuelve a mencionar sólo el caso de Teresa. Jaffary, Nora Elizabeth: Deviant Orthodoxy: a social and cultural History of ilusos and alumbrados in colonial Mexico, Ph.D. diss., Columbia University, New York, 2000, págs. 179 y ss. habla de las cuatro hermanas pero sin abundar en sus procesos.

2 Los Márquez de Amarillas se encontraban avecindados en la ciudad de Puebla desde 1556. Leonor Montenegro, esposa de Juan Márquez de Amarillas (ambos originarios de Toledo) fundó el convento de Santa Catalina de Sena de la ciudad, el cual empezó a funcionar en 1568. Uno de sus hijos fue racionero de la catedral de Puebla y el otro fue propietario de un ingenio azucarero en Izucar de Matamoros. Ambos hijos renunciaron a su herencia paterna en favor de su madre con objeto de terminar el que fue el primer convento de monjas dominicas de Iberoamérica. Agradezco a Rosalva Loreto esta información que aparecerá en un artículo suyo próximo a publicarse. 
una joven de nombre Catalina Morales, muy posiblemente una hija ilegítima de don Juan. Sin embargo, el cambio de ciudad no mejoró la fortuna de los Romero, cuya situación era tan precaria que cuando nació en 1631 Teresa, la última de sus hijas, tuvo que ser enviada a Atlixco a criarse en la casa de una parienta. ${ }^{3}$

A partir de entonces, la desesperada situación de Juan Romero cambió, pues su hermano, el dominico fray Lucas Zapata, que vivía en Tepetlaoztoc, lo mandó llamar para que se hiciera cargo de la administración de las haciendas del convento. Gracias a su relación con los dominicos, don Juan se fue enriqueciendo con el cargo de alguacil mayor amparador de los indios; les pedía ("hacía derrama") un pollo a la semana por casa, les cobraba cuatro reales a los que faltaban a la misa dominical y a varios los despojó de sus bienes; por estos medios llegó a hacerse de una casa propia malamente arrebatada a una familia del pueblo. Llegó a ser tan desahogada su situación, que don Juan pudo desposar a su hija María con Diego Pinto, a quien ocupaba como vaquero de un cortijo con vacas recién adquirido con sus métodos habituales. Ocho años después de su llegada a Tepetlaoztoc, los Romero hicieron traer a Teresa desde Atlixco. Las cosas parecían ir sobre ruedas hasta que la ambición rompió el saco. Los abusos de don Juan y la falsificación de memoriales con los nombres de los indios principales para sacar beneficios a su favor (para lo cual contaba con el apoyo del gobernador de Texcoco), provocaron que la justicia lo despojara de los bienes mal habidos. La familia Romero se vio forzada a salir de Tepetlaoztoc en 1646, entre los gritos y las amenazas de los indios, y se dirigió a la capital, donde don Juan tenía otro pariente dominico, fray Cristóbal de Pocasangre. ${ }^{4}$

Una vez asentados en la ciudad de México, en una casa del barrio de Santa Catalina, y gracias a la ayuda de su "tío el fraile", las hermanas Romero (salvo María que se fue a vivir con su marido y sus tres hijos a las huertas del marqués del Valle de Oaxaca en San Cosme) pudieron introducirse poco a poco en la sociedad capitalina. Desde que vivían en Tepetlaoztoc, las hermanas se habían destacado por su capacidad de comunicarse con el más allá y por sus extraordinarias dotes histriónicas, e inclu-

3 Las declaraciones contra Josefa, Nicolasa, Teresa y María se encuentran en los volúmenes 432, 433 y 1499 del ramo Inquisición del Archivo General de la Nación, citado en adelante con las siglas AGN.

4 Testimonio de fray Agustín Fonseca, México, 7 de agosto de 1650. AGN, Inquisición, 432, fol. 250 r. y ss. Este fraile es quien da más noticias sobre la estadía de los Romero en Tepetlaoztoc, donde él los conoció. 
so habían cambiado sus apellidos por los de los santos protectores que, según ellas, las habían elegido. Entre todas, Nicolasa de Santo Domingo era la menos dotada pues, aunque tenía ataques de epilepsia que le permitían una actuación muy natural, su cortedad no le daba oportunidad de brillar con la labia y el despliegue teatral de sus hermanas, sobre todo de las mayores, María de la Encarnación y Josefa de San Luis Beltrán. La segunda sobre todo, con un gran talento natural y una memoria aguda, poseía una personalidad carismática remarcada aún más por un defecto físico: tenía seco el brazo izquierdo. La menor, Teresa de Jesús, había mostrado una gran rebeldía y una moral muy relajada desde su estadía en Tepetlaoztoc, quizá como consecuencia de su abandono en Atlixco; la necesidad de ser aceptada por su padre la llevó a imitar las atrevidas acciones de la primogénita, con la que muy pronto entabló una feroz competencia. Cuando Josefa se presentó con heridas en la frente que parecían producidas por una corona de espinas, Teresa arrojó al día siguiente espumarajos de sangre por la boca. El conflicto entre las hermanas terminó abruptamente cuando Teresa, golpeada en la cara con unas varas por Josefa, huyó de la casa paterna. $^{5}$

Para sustentarse, las hermanas decían dedicarse a tejer mantas de lana delgadas, de las que solían hacer túnicas los religiosos. En un principio sus vestidos eran viejos y Teresa muy pronto adoptó el sayal del Carmelo y se rapó la cabeza. El ajuar de su casa fue siempre muy modesto: un petate, una imagen y un cofre. Aunque no poseían libros, los conseguían prestados de sus amigos sacerdotes o laicos y los comentaban después de hacer su lectura en familia, sobre todo bajo la dirección de su padre Juan Romero. Al parecer las tres hermanas habían aprendido a leer, pero es muy probable que no supieran escribir. Aunque a menudo las razones que dan para haber realizado los engaños fueron la indigencia y la falta de recursos, no debe descartarse que ésta haya sido una excusa para obtener clemencia de los jueces y que detrás de sus actitudes hubiera también una necesidad de llamar la atención y de adquirir prestigio y presencia sociales.

Como marginadas, estas mujeres crearon estrategias efectivas de acomodación, mediación y resistencia ante la institución eclesiástica. Sin duda esto fue posible gracias a que la sociedad era también bastante flexible para integrarlas y aceptarlas, a pesar de la propaganda que contra ese tipo de manifestaciones generaban algunos sectores clericales. Además, aunque

5 Testimonio de Francisco Antonio de Loaysa, México, 1 de junio de 1650. AGN, Inquisición, 432 , fol. $158 \mathrm{r}$ 
era común que las mujeres españolas solteras tomaran el velo monástico o ingresaran en un recogimiento o en una orden tercera, es significativo que estas hermanas se mantuvieran fuera de tales organizaciones. Con todo, Josefa y Teresa utilizaron a menudo la posibilidad de entrar a la clausura monacal (a la segunda incluso se le consiguió dote para San Jerónimo) como método para afianzar su credibilidad ante los demás.

\section{Seguidores, benefactores y confesores}

Una de las características más destacadas de las sociedades occidentales del Antiguo Régimen es su capacidad para aceptar el prodigio como algo cotidiano y su necesidad de buscar soluciones a los problemas diarios en las fuerzas celestiales. Una gran cantidad de intermediarios ofrecían satisfactores para tales demandas: desde los sacerdotes que administraban la religión católica y sus prácticas y devociones (misas, sacramentos, escapularios, rosarios, reliquias, peregrinaciones, imágenes, etcétera), hasta los curanderos y hechiceros que, a pesar de estar proscritos por demoniacos, ofrecían soluciones más directas para la curación de las enfermedades, la atracción de la buena fortuna o la obtención de favores amorosos. Entre estos dos grupos de oferentes de "mercancía espiritual" se encontraban las llamadas "beatas" y los ermitaños. Al moverse en ámbitos avalados por la ortodoxia, pues su actuación se encontraba dentro de los límites de lo permitido, tenían mayores posibilidades de evadir los controles inquisitoriales; por otro lado, estos laicos cubrían necesidades que ni el clero ni los hechiceros habían explotado, como era la comunicación directa con el más allá. A cambio de estos servicios, tales personas tocadas por un don divino recibían limosnas en metálico, bienes suntuarios como imágenes, ropa, azúcar, tabaco y, a veces, hasta techo, comida y una renta mensual para su mantenimiento. De hecho, las hermanas Romero comenzaron a vestirse con mejores ropas a raíz de estos regalos. Las autoridades no veían con malos ojos que a cambio de los favores espirituales se recibieran dinero u otros beneficios, además de que muchas de las limosnas que estas mujeres recolectaban se destinaban a las misas por las ánimas del purgatorio, y por tanto llegaban finalmente a manos de los clérigos y a sus templos.

Las hermanas Romero, a quienes los vecinos comenzaron a llamar con el apelativo de "las santitas", muy pronto se rodearon de un número considerable de seguidores, atraídos por su fama y por el aval de algunos 
sacerdotes que las rodeaban. Al principio, lo común era que ellas fueran invitadas a las casas de sus benefactores, que reunían tertulias para presentarlas ante la sociedad; en esas reuniones "las santitas" entraban en rapto, traían ante la concurrencia a las almas del purgatorio (que no siempre eran las que solicitaban sus devotos) y pedían a Cristo la solución de sus necesidades. Pero poco a poco, una vez que reunieron un número considerable de seguidores, comenzaron a recibir en su casa y a realizar sus actuaciones en sus alcobas.

De las cuatro hermanas, sin embargo, sólo dos lograron afianzar un grupo de seguidores: Josefa y María. La primera utilizó un método sumamente novedoso para atraerse la atención de los más destacados personajes que llegaban a su casa. De tres en tres días Josefa había ido eligiendo a cada uno de sus "celadores", mandando que les fuese avisada su designación para tan honorífico cargo. Por los documentos del proceso sabemos que entre ellos había seis clérigos y seis laicos que serían testigos de los prodigios. Pero a Josefa no le bastó con hacer tales analogías con Cristo y sus apóstoles; en una ocasión que los reunió a todos, fingiendo que cogía un jarro de agua, se puso una estola sobre los hombros como lo hacían los sacerdotes y lavó los pies de los presentes, los secó y los besó, después de levantar los ojos al cielo frente a cada uno, como preguntando si con la persona que tenía enfrente debía o no hacer tales acciones. ${ }^{6}$ Entre esos doce elegidos estaba un joven clérigo navarro, (que aún no tenía la ordenación sacerdotal) llamado Joseph Bruñón de Vértiz, ex combatiente en las guerras españolas, que buscaba pasar a Oriente a morir martirizado. Josefa quedó prendada de él y, al enterarse de sus intenciones de entregarse al martirio, no le fue difícil convencerlo de quedarse en México a esperar la manifestación de lo que Dios quería de él.

María, la hermana gemela de Josefa, también reunió en torno a ella a un grupo de seguidores en una casa en las huertas del Marqués, donde vivía con un marido vago y tres hijos que debía mantener. Su gran necesidad la llevó a fingir raptos, idea inspirada por el éxito que sus hermanas estaban obteniendo. Entre sus oyentes se encontraba su propio benefactor Juan Mestre (el administrador de las huertas), el suegro de éste, Diego Manuel de la Rocha (secretario del Consulado), los clérigos Venegas y Trujillo, fray Cristóbal de la Cruz (limosnero de los descalzos de San Cosme), fray Juan Bautista (un dominico de San Jacinto), Alonso de Mesa (alguacil mayor de

6 Ibidem, fol. $140 \mathrm{r}$. 
visita), el herrero Diego Muñoz Tercero, el canónigo Martín de Espinosa y el médico Lucas Cárdenas. La "beata" tenía raptos los martes y los viernes y con ese pretexto se hacían en su casa animadas tertulias. A ellas llegó también tiempo después Joseph Bruñón de Vértiz como veremos. ${ }^{7}$

Como se puede observar, entre los seguidores y benefactores de las hermanas Romero se encontraban tanto eclesiásticos como laicos, y entre éstos gente de todos los estratos sociales, desde funcionarios de los tribunales y secretarías del virreinato, hasta medianos y modestos artesanos. Uno de estos laicos fue el fabricante de velas (cerero) Francisco Antonio de Loaysa, hombre de mediano caudal, quien les había regalado vestidos y joyas de su mujer Ana de la Parra y las recibía a menudo en su casa; ahí pasó a vivir Teresa de Jesús después de la pelea con su hermana Josefa. Por varios testimonios sabemos que este hombre hospedaba también a menudo a los ermitaños que llegaban a la ciudad a arreglar algún asunto como fray Bartolomé de Jesús María (el agustino lego mestizo de Chalma) y Francisco de la Cruz o Pereira, un portugués que declaró en el juicio de Josefa de San Luis Beltrán. Este hombre, que había sido latonero y que vestía con la sotana parda corta propia de los ermitaños, declaró que Teresa tenía mucha familiaridad con sus devotos, les besaba en los carrillos y se dejaba abrazar por ellos. Además declaró que, mientras estaba en su arrobo, dijo que a Juan Cortés (un joven aprendiz de cerero con el que tenía amoríos) lo había convencido para que entrara de fraile. ${ }^{8}$ Esa familiaridad con los laicos también la tenían con algunos frailes. En Tepetlaoztoc, Josefa jugaba con los dominicos a las cartas, "chocarreaba y parlaba con ellos por lo que el pueblo la tenía en mala opinión por el desenfado de sus acciones". ${ }^{9}$

Sin duda, uno de los factores de su éxito fue esta cercana relación que las hermanas tuvieron siempre con los clérigos. Al principio éstos eran sobre todo frailes de Santo Domingo y los curas seculares de la parroquia de Santa Catalina en cuya demarcación vivían; pero después llegaron los carmelitas, los franciscanos descalzos y algún jesuita atraídos por su fama. De entre ellos salieron sus confesores y directores de conciencia. Es también notable la presencia constante de frailes que pasaban a Filipinas, a 120 r. y ss.

7 Testimonio de Juan de Mestre, 14 de diciembre de 1649. AGN, Inquisición, 433, fols.

8 Testimonio de Francisco de la Cruz o Pereira, Xamatitlán, valle de Amilpas, 9 de octubre de 1649. AGN, Inquisición, 432, fols. 282 r. y ss.

9 Testimonio de fray Agustín Fonseca, México, 7 de agosto de 1650. AGN, Inquisición, 432, fol. 249 r. y s. 
quienes daban consejo y animaban para que no se entibiara su vocación misionera. Para halagar a los sacerdotes, Josefa y Teresa los llamaban "los ungidos", y a varios de ellos les encomendaban la misión de decir las misas por las almas del purgatorio solicitadas en los raptos. Algunos de estos clérigos manifestaban un abierto apoyo a las "beatas". En una ocasión que estaba en México fray Bartolomé de Jesús María, ermitaño lego que habitaba en la cueva del santuario de Chalma, oyó comentarios en el convento de San Agustín sobre los embustes de las embaucadoras del barrio de Santa Catalina y la alusión llegó a Josefa a través de Francisco Antonio, en cuya casa el ermitaño se alojaba. Cuando fray Bartolomé fue a visitarla, ella expresó en un arrobo las palabras que el ermitaño había escuchado en el convento agustino, lo que asombró al fraile, quien desde entonces se manifestó favorable a ella.

En otras ocasiones, los religiosos iban a pedirles ser encomendados a la divinidad, como fue el caso de algún dieguino que pasaba a Filipinas y que llegó con Nicolasa a solicitar su intercesión para que Dios le quitase una aflicción que tenía y que no le dejaba sosegar en la oración y demás ejercicios. "Volvió el dicho religioso solo a verla a su casa — señala la "beata" en su declaración- y le reclamó que no hacía lo que le había pedido pues no se le había quitado aquello que lo desasosegaba, y le suplico se lo pidiese a Nuestro Señor muy de veras y que advirtiese que de todas sus hermanas sólo a ella se inclinaba su espíritu".${ }^{10}$ Sin embargo, junto a esta actitud de aceptación por parte del clero, las "beatas" tuvieron que enfrentarse también a su oposición, como veremos.

Pero la relación más cercana y directa con el clero era aquella que se establecía con los confesores y directores de conciencia. En la teoría, el fiel debía elegir para tal función a aquel sacerdote que tuviera la sabiduría y la calidad moral necesarias para servir de guía en el azaroso mundo de la vida espiritual; pero en la práctica, estas mujeres (al igual que muchos otros laicos) tendían a preferir a aquellos más flexibles y tolerantes con las debilidades humanas o, en el caso de estas "beatas", a aquellos que se mostraran más proclives a aceptar sus visiones o que les daban mayor prestigio. Teresa, por ejemplo, eligió por confesor al carmelita fray Juan de San Pablo durante el tiempo en el que su probidad moral se ponía en duda, "pues oyendo decir que la confesaba un padre del Carmen la dejarían sus ému-

10 Testimonio de Nicolasa de Santo Domingo, México, 30 de julio de 1650. AGN, Inquisición, 433 , fol. $135 \mathrm{r}$ 
los". ${ }^{11}$ Sus elecciones anteriores de confesor no habían sido menos veleidosas, además de haberlas acompañado con toda un aparato "visional". Así fue la nominación que hizo del clérigo Diego Juárez entre todos los curas de la parroquia de Santa Catalina, al cual llegó siguiendo una visión en la que Cristo con la cruz a cuestas la llevaba hasta el confesionario que ocupaba ese sacerdote en el templo.

Pero en esta relación no sólo las "beatas" se benefician con el prestigio o ratificación de los clérigos, éstos también obtenían un reconocimiento público al dirigir a tan virtuosas almas. Las confesadas establecían fuertes vínculos con sus confesores, a pesar de lo poco recomendable de las relaciones entre laicas y clérigos, para no mencionar los prejuicios existentes contra las mujeres solas y los estrictos códigos que regulaban la aprobación de los auténticos místicos que había institucionalizado la Iglesia de la Contrarreforma. ${ }^{12}$ En la confesión, el sujeto construye su propia verdad a partir de lo que él supone que el confesor está dispuesto a escuchar; con ello se establece una dependencia por ambas partes pues, junto al control del acto dirigido por quien tiene la autoridad moral, existe también la posibilidad de manipulación de aquel que está dando el informe de su vida interior. Sucede incluso a veces que la relación se revierte y los confesores solicitan el consejo o hacen uso de las capacidades intercesoras de sus confesadas.

Sin duda una de las razones por las que estas "beatas" visionarias pudieron continuar con sus actividades fue la actitud humilde y sumisa que mostraban ante sus confesores. Sin embargo, esa relación armoniosa no podía durar por mucho tiempo; la mayor parte de los directores de conciencia no veían con buenos ojos el concurso de gente alrededor de las "santitas" ("recelaban a que tanta virtud se enfriase con la publicidad y el aplauso"), ni tampoco el aparato que rodeaba a las visiones. En una ocasión, fray Lorenzo Maldonado, confesor de Josefa, le aconsejó que pidiese a Cristo la llevase por camino de amar, más que por camino de ver, pues aquel era más seguro y este otro muy peligroso. Juan Romero, que estaba escuchando el consejo, se disgustó mucho y dijo al sacerdote que no se entrometiera, que en eso no tenían jurisdicción los confesores, pues eso era gobernar su casa. ${ }^{13}$

11 Carta testimonial de fray Lorenzo Maldonado, 21 de febrero de 1650. AGN, Inquisición, 432 , fol. 438 vta.

12 Jaffary, op. cit., p. 65.

13 Carta testimonial de fray Lorenzo Maldonado, 21 de febrero de 1650. AGN, Inquisición, 432 , fol. 440 vta. 
Estas prohibiciones y limitaciones, o el excesivo cuestionamiento o escepticismo, eran a menudo causa suficiente para cambiar de confesor, aunque a menudo éste mismo era quien abandonaba la dirección de conciencia, no sin dejar siempre un sustituto. De las cuatro hermanas, Josefa fue la que se mostró más insumisa a sujetarse a los dictados de los confesores, con quienes tuvo una relación muy conflictiva durante los últimos meses de su actuación. A raíz de una serie de pruebas que le hicieran los dominicos fray Rodrigo de Medinilla y fray Agustín Fonseca para dirimir si su posesión era divina o demoniaca, Josefa llegó a declarar, con la voz de Cristo, la necesidad de liberarse del yugo de sus confesores, los acusó de embusteros, ciegos y sordos, y les recordó que el buen confesor era un guía que azuzaba al alma para la perfección, no el que se la impedía. $\mathrm{Al}$ final, cuando los confesores le prohibieron tener visiones, ella se arrobaba y hablaba de los padecimientos de Santa Catalina de Siena y de Santa Teresa causados por unos confesores que no las comprendían. ${ }^{14}$

El conflicto con los confesores se traspasó a menudo a otros sectores sociales con los que éstos tenían relación, como sucedió entre Josefa y sor Isabel de Jesús, monja del monasterio de Santa Clara. La "beata" había convencido a uno de sus celadores, el mercader Pedro López de Covarrubias, que aplicara a las almas del purgatorio ciertos fondos que sor Isabel le había solicitado para las obras de su convento recién dañado por un temblor. La monja se enteró del hecho por fray Agustín Fonseca y mandó llamar a la beata para reprenderla, le reclamó por el daño que hacía a las almas del purgatorio con sus engaños y le ordenó que cambiara sus vestidos lujosos por un pobre sayal y que ingresara como terciaria dominica. Cuando salió del locutorio, Josefa regaló el hábito raído que la monja le obsequiara y mandó escribir a su hermano Juan varias cartas a otras monjas para desacreditar su virtud. ${ }^{15}$

En abierto contraste con esta relación conflictiva con las religiosas, está la posición de la hermana de Josefa, Nicolasa de Santo Domingo, quien visitaba frecuentemente a sor Leonor de la Ascensión, religiosa del convento de San Juan de la Penitencia, para pedirle consejo. En una ocasión la monja le aseguró que lo que ella tenía "era presencia continua de Dios y que procurase conservarla y advirtiéndole que Cristo Nuestro Señor era muy celoso y por muy leve descuido que tuviese la dejaría y no senti-

14 Estaciones de Josefa de San Luis Beltrán. AGN, Inquisición, 1593, fol. 214 r. y 254 vta.

15 Testimonio de fray Agustín Fonseca, México, 7 de agosto de 1650. AGN, Inquisición, 432, fol. 261 r. y ss. 
ría aquello, con que después procuró vivir con el ajustamiento que debía su conciencia". ${ }^{16}$

\section{Los mecanismos de atracción: las virtudes, las visiones, las enfermedades}

Una de las causas principales por las que las hermanas Romero eran tan bien recibidas en los ámbitos clericales y laicos fue sin duda su apego a las normas morales y religiosas de la ortodoxia. En su testimonio ante los inquisidores, fray Rodrigo de Medinilla aseguraba: "Consultadas de lo que sentían después de estos arrobos y lo que sacaban de ellos respondían que reformación de vida por hallarse otras de lo que eran primero, fervoroso amor a Dios Señor Nuestro [y] valor para padecer por su majestad. Por lo cual especié de tanta virtud y aprovechamiento, y no haber hallado en ellas desenvoltura o notas de torpeza, que es lo primero con que pinta la malicia de la mujer y no haber encontrado entonces... motivo para sospechar... y ser hijas de padres, al parecer, preciados de buenos cristianos y honrados". Y poco después agregaba "Aunque había misceladas muchas ilusiones, había mucho bueno en ellas, había virtud y propósito de enmienda... el modo de satisfacer a las dudas me pareció exceder siempre el caudal de una mujercilla y me vine a persuadir en que era espíritu el que en ella hablaba sin dar lugar a la duda, aunque entonces no acababa de discernir si era bueno o malo". ${ }^{17}$

El pertenecer a una familia criolla y honesta, el mostrar sumisión y humildad (Josefa se llamaba a sí misma hormiguilla y cordera llena de roña) y el haber hecho voto de castidad eran tres bases importantes de credibilidad para una sociedad que vivía en un mundo de símbolos. De eso estaban plenamente conscientes las hermanas Romero, tanto que siempre procuraron mantener una imagen de decencia y buen comportamiento. De hecho, cuando Teresa regresó a la casa paterna embarazada por Juan Cortés (un oficial de Francisco Antonio de Loaysa en cuya casa estaba hospedada), procuraron ocultarla a los ojos de sus seguidores y al nacer la criatura la dieron en adopción.

16 Testimonio de Nicolasa de Santo Domingo, México, 30 de julio de 1650. AGN, Inquisición, 433, fol. 134 vta.

17 Testimonio de fray Rodrigo de Medinilla, México, 4 de junio de 1653. AGN, Inquisición, 432 , fol. 182 r. y vta. y 189 r. 
Pero sin duda la mayor atracción, lo que causaba asombro y temor, pues ponía a los mortales en contacto con el mundo sobrenatural, eran los raptos. Las cuatro hermanas habían comenzado a tener este tipo de manifestaciones desde su estancia en Tepetlaoztoc. Durante ellos recibieron de sus respectivos santos protectores sus nombres religiosos y ahí fue también donde aprendieron sus primeras lecciones de mística por parte de su tío fray Cristóbal de Pocasangre. Con él, y con la gran cantidad de clérigos que las seguían, supieron distinguir entre un coloquio y un soliloquio, conocieron la diferencia entre los raptos de unión, en los que no se pronunciaban palabras, y los vocales, en los que sí. Otros de estos conocimientos los adquirían por los libros prestados por los clérigos y leídos en familia en voz alta. Textos como los Suspiros de San Agustín, Las Moradas de Santa Teresa o Las Peñas de fray Enrique Suzón les dieron abundantes ideas para sus visiones. Con ese conocimiento de mística casera las mujeres pudieron crear las bases de credibilidad que les exigían sus confesores.

Sin embargo, el aspecto teórico no era suficiente. Para atraer a sus seguidores hacía falta un segundo elemento: introducir en los raptos datos personales de sus oyentes. Gracias a los informes que les proporcionaban los vecinos, la hermanas pudieron meter en sus visiones los detalles de las vidas privadas de quienes acudían a pedir consejo y ayuda. De ellas dice el diarista Gregorio de Guijo: "Dicen eran sabedoras de todos los sucesos de las personas del reino, y en los trabajos y necesidades, pérdidas y otras cosas decían dónde estaban, y lo perdido se hallaba dándoles la limosna que ellas pedían. Andaban (según noticia) muy ricamente aderezadas y eran visitadas de todo el reino". ${ }^{18}$

Ese "conocimiento de las cosas ocultas y de las conciencias" que poseían las hermanas aportaba una enorme confianza en su capacidad intercesora. Junto con esa información obtenida del entorno se integraron también sus propias experiencias personales (posición social, sexualidad, vida familiar) en su comprensión y explicación de la ortodoxia. ${ }^{19}$

Por los testimonios del juicio sabemos que todos los raptos iban acompañadas con actuaciones, gestos, tullimientos y movimientos corporales. Joseph Bruñon aseguró que levantaban los ojos con fijeza o cerrados, inclinaban la cabeza hacia las espaldas, los brazos los apretaban contra su cuerpo o los ponía en forma de cruz y se arrastraban por el piso. Colocaban

18 De Guijo, Gregorio Martín: Diario (1648-1664), 2 v., México, 1986, v. I, pág. 67.

19 Jaffary, Deviant Orthodoxy..., pág. 13. 
los dedos hacia afuera o los doblaban sobre la palma de las manos, ponían un pie sobre el otro y demudaban el semblante. ${ }^{20}$ En los llamados "raptos de simpleza" hablaban como criaturas, tiraban la comida y pedían tabaco y chocolate. Algunas veces en estos raptos el balbuceo de las palabras era inaudible, por lo que se hacía necesario que su padre Juan Romero acercara el oído e interpretara "sus razones y acciones de sus raptos y exageraba y ponderaba lo que veía y oía". ${ }^{21}$

El impacto de las visiones de las hermanas llegó incluso a afectar a la servidumbre. Pedro López de Covarrubias narra que vivía en la casa de los Romero una indiezuela llamada Jerónima que vivía "en un aposento debajo de la escalera que le habían prevenido para que pariese pues después de haberse huido de la casa, había regresado preñada". Un día esta india fingió un rapto rezando el pater noster, con los ojos abiertos y sin pestañear miraba al techo y cantaba con voz sumisa y entonada unas coplas en mexicano (náhuatl) sobre la coronación de espinas y otra sobre los azotes, y daba a entender que veía a Santo Domingo y a Cristo y que esos favores se los hacían en atención a la criatura que llevaba en el vientre. "Cuando le fueron a avisar a Josefa lo que pasaba, ésta bajó enfurecida y riñó a dicha india diciendo que eso era fingido y mentira, desde entonces nunca más se arrobó y después de que parió la despidieron". Como un dato anecdótico, el padrino de la criatura fue el mismo Pedro López de Covarrubias. ${ }^{22}$

De las cuatro hermanas, era Josefa la que tenía las visiones más elaboradas, llenas de imágenes que parecían sacadas de las pinturas: pilas de plata, columnas de cristal, elefantes, jardines con pájaros, leones, tunales y águilas coronadas, ciudades y escenas bíblicas. Decía también que viajaba por Roma, Madrid, el Jordán y hasta Japón, donde vio morir a los mártires. Pero su mayor virtud consistía en imitar voces. Pedro López de Covarrubias, cuenta en su testimonio: "Se ofrecía en el rapto hablar como el Señor, o como su Santísima Madre, como un santo o como un alma en pena. Hablaba por todos los personajes sin confundirse la inteligencia de los unos con los de los otros. Como cuando uno lee una comedia que habla

20 Testimonio de Joseph Bruñón de Vértiz, 7 de octubre de 1649. AGN, Inquisición, 432, fol. 359 r. y s.

21 Testimonio de Francisco Antonio de Loaysa, México, 1 de junio de 1650. AGN, Inquisición, 432 , fol. 141 r. y s.

22 Testimonio de Pedro López de Covarrubias, México, 4 de abril de 1650. AGN, Inquisición, 432 , fol. 445 r. y vta. 
por todos los personajes de manera que se entiende cuando uno deja de hablar y comienza otro. No faltaba en esto mudanza en el tono, más recio o más bajo, más blando o más severo". ${ }^{23}$ Durante su puesta en escena, Josefa narraba sus visiones, y una vez concluida, de su boca salía la voz ronca de Cristo que explicaba las imágenes contenidas en ella y daba la enseñanza moral pertinente.

A menudo esas moralejas estaban relacionadas con las ofensas que los pecadores cometían contra Dios, la irreverencia en las iglesias, la frialdad de los ministros, los devaneos de las monjas con sus devotos en los locutorios, la fe débil y la moral ambigua de los laicos. Era frecuente que las visiones sirvieran también para reforzar su posición o para desacreditar a los que la atacaban. Cuando se enfrento a sor Isabel, la monja de Santa Clara, Josefa expresó con la voz de Cristo que el cambio de hábitos externos era algo secundario, y con otra visión desacreditó la opinión de que la religiosidad de los terciarios fuera mejor que la de los demás fieles, clara alusión a la preferencia de Josefa por mantenerse libre de toda atadura institucional. ${ }^{24}$

Pero la actuación de Josefa fue más allá. Después de decirle que tenía en la frente la señal de los elegidos, pidió a Joseph Bruñón (con la voz de Cristo) que fuera su secretario y que transcribiera todos los coloquios sostenidos entre la divinidad y su sierva. Vértiz encontró en esta elección una razón para vivir y se entregó a su trabajo con una devoción absoluta. A lo largo de dos años y medio Josefa revisó minuciosamente las notas, corrigió aquello con lo que no estaba de acuerdo y mandó a su secretario trasladarlas en limpio para tener una copia. Su hermana Teresa quiso imitarla y pidió a su padre y a su hermano Lucas que hicieran lo mismo con sus raptos, pero Josefa insistió en que fuera mostrado el cuadernillo a fray Lorenzo Maldonado, y éste lo mandó quemar diciendo que estaba lleno de errores. Y no era para menos. En una de sus escenificaciones, Teresa había comenzado simulando cargar con una cruz sobre sus hombros y terminó en el suelo con el cabello alborotado y el rostro amoratado y lleno de gargajos. ${ }^{25}$

Tanto las visiones (muchas de ellas relacionadas con el tema de Cristo como esposo) como el ascetismo exacerbado (ayunos y azotes) formaban

23 Ibidem, fol. 468 vta.

24 Ibidem, fol. 461 r. y s.

25 Testimonio de Diego Juárez de Araujo, México, 21 de febrero de 1650. AGN, Inquisición, 432 , fol. $246 \mathrm{r}$ 
parte de la herencia hagiográfica femenina bajomedieval que las Romero habían recibido de sus lecturas y de las lecciones clericales. De ellas también tomaron un ejemplar manejo de la enfermedad, tema central de ese cristianismo emotivo y sufriente aparecido en el siglo XIII. El padecer es utilizado como un acicate para el crecimiento espiritual, como el fuego que purifica al alma de sus imperfecciones, pero también es mostrado ante quienes las admiran y siguen como una prueba de la elección divina sobre sus personas.

Además de las enfermedades comunes, las hermanas sufrían tullimientos, los cuales eran anunciados con antelación y duraban hasta cuarenta días. Durante uno de estos lapsos, Josefa fue invitada a ser madrina de bautizo y para cumplir con su compromiso simuló conseguir del Señor una interrupción temporal de su malestar.

Aunque a veces las enfermedades parecían fingidas, a menudo eran patentes los efectos físicos. Pedro López de Covarrubias aseguraba que un día la vio "con el pecho izquierdo hinchado y duro como un tecomate, muda porque tenía la lengua recogida a la campanilla que no podía hablar, ni toser, ni estornudar". Don Pedro le puso la imagen del niño Jesús sobre el pecho y "la lengua volvió a su lugar como cuando una sanguijuela se desenrolla" ${ }^{26}$ En otra ocasión Nicolasa "la halló en la cama en brazos de su hermano Juan [con] el celebro [sic], rostro y manos hinchados como un mostro [sic] y que tenía dolores en todo el cuerpo". Los médicos recomendaron se pusiera "tres hígados calientes de carnero en la cabeza". ${ }^{27}$ Por su parte, Teresa y Nicolasa decían padecer mal del corazón, enfermedad que varios testigos del juicio describen así: "cuando les da el dicho mal no hablan, sino que se están echando espuma por la boca".

Con tal cantidad de recursos, las "beatas" lograban captar la atención de sus devotos, una atención que debía alimentarse continuamente con nuevos medios y a cuyas exigencias tenía que amoldarse su actuación. Junto con la atención se buscaba también provocar en el auditorio pavor o arrepentimiento y, a la larga, apoyo moral y material incondicionales. De hecho era ese apoyo de la comunidad el que forjaba su fama de santidad, una fama en la que finalmente quedaban atrapadas, pues el prestigio que habían adquirido y las exigencias de su auditorio les impedían detenerse.

26 Testimonio de Pedro López de Covarrubias, México, 4 de abril de 1650. AGN, Inquisición, 432 , fol. $457 \mathrm{r}$.

27 Testimonio de Nicolasa de Santo Domingo, México, 13 de septiembre de 1649. AGN, Inquisición, 432, fol. 314 r. y s. 


\section{Las creencias y las prácticas religiosas reflejadas en los procesos}

Además de las virtudes y las visiones, la otra razón por la que estas "beatas" pudieron continuar con sus actuaciones, sin caer de inmediato bajo la censura inquisitorial, fue su respeto a las instituciones y su acertado manejo de los dogmas y de las devociones avaladas por la ortodoxia. Su liderazgo se debía en buena medida a que se sometían incondicionalmente a los términos que la sociedad les imponía. ${ }^{28}$ En todas sus visiones estaba presente un absoluto respeto por las jerarquías civiles, eclesiásticas y militares y un discurso que recomendaba las virtudes propias de un súbdito sumiso al rey y a Dios: temor, obediencia, resignación, arrepentimiento, fervor. Esta asimilación al sistema de valores tradicional se puede ver incluso en sus declaraciones de apoyo al tribunal del Santo Oficio (al que llamaban defensor de la fe) y en sus ataques contra los judíos que se encontraban por entonces en las cárceles inquisitoriales en espera de juicio. En uno de sus raptos, Josefa dijo de ellos que eran grandes bellacos, "que cogían lo redondito del pan (que es el sello) y lo tiraban por la ventana de su casita (que así llamaba a la cárcel secreta) y que hacían muchas bellaquerías acá dentro contra su tata Dios, y que no querían creer que había venido su tata Dios al mundo". ${ }^{29}$

En donde se ve con mayor claridad el manejo ortodoxo de conocimientos teológicos básicos es en el tratamiento de temas místicos (como los diversos estados de la gracia y los grados de perfección) y sobre todo en los asuntos relacionados con la naturaleza del purgatorio y del infierno. En estos temas también Josefa era una experta; en una ocasión, su hermana Teresa dijo haber visto un alma saliendo del infierno y Josefa corrigió tal error teológico señalando en latín: en el infierno "nulla est redemptio" (no hay redención)..$^{30}$

El tema del purgatorio era uno de los más socorridos en la cultura visionaria femenina. En Josefa aparecen continuamente referencias a él, incluso con la mención a una creencia al margen de la ortodoxia muy difundida en el mundo católico novohispano, la del "penaculario", un lugar

28 Jaffary, Deviant Orthodoxy..., p. 83 y ss.

29 Testimonio de Hernando de la Fuente, México, julio de 1650. AGN, Inquisición, 432, fol. 136 r. Seguramente se refiere al sello que tenían a menudo los panes y no a la hostia, pues era difícil que los judíos tuvieran acceso a una forma, aún sin consagrar, en la cárcel. La frase es oscura pues parecería hacer alusión a un sacrilegio.

30 Testimonio de fray Rodrigo de Medinilla, México, 4 de junio de 1653. AGN, Inquisición, 432, fol. $199 \mathrm{r}$. 
del purgatorio "donde son tan sin explicación las penas que se padecen, que sólo las que uno siente pudieran servir por muchas de los que están más arriba". ${ }^{31}$ Para disminuir esas penas, Josefa y sus hermanas recomendaban a sus devotos adquirir las bulas de Santa Cruzada, consejo que ellas mismas seguían para evitar los escrúpulos de conciencia, cuando al confesarse dudaba si habían hecho una buena confesión.

El tratamiento del tema del más allá se exacerbó cuando los confesores le prohibieron tener visiones del purgatorio; Josefa, con la voz de Cristo, les respondió que hacían mal, pues era el mismo Dios quien enviaba a esas almas a pedir sufragios por mediación de su sierva. Pedro López de Covarrubias calculó en 24,000 las almas que habían salido del purgatorio por su intercesión, algunas de ellos de negros bozalitos "porque pobrecitos no hay quien se acuerde de ellos". Pero Josefa también se preciaba de haber sacado de ahí a las almas de hombres ilustres como Richelieu, el conde duque de Olivares y hasta Moctezuma. Este último personaje salió a relucir a raíz de un comentario que hizo Pedro López, quien había asistido a un mitote de los indios en un tablado y que, enternecido con la figura de Moctezuma, había preguntado a Josefa por la suerte de un rey tan digno y justo. La vidente le aseguró que el monarca azteca no se había condenado. Con la voz de Cristo dijo: "Mis juicios son diferentes de los de los hombres. Como no ha habido quien por él haya rezado un pater noster no ha salido. El rey pidió el bautismo y quien le dio palabra de administrárselo le faltó con ella. Después le mataron hiriéndole de sangre y tiranizándole el imperio de su mundo. Pedid por él que me agradaréis. Seis años le faltan con algunos días". ${ }^{2}$

Muy frecuente era también en las visiones la mención al cielo, espacio definido siempre en los términos físicos de la pintura. Nicolasa, después de haber dejado las meditaciones de la pasión de Cristo por orden del jesuita Baltasar López, se dedicó a meditar sobre los tres lugares: "Sobre todo el cielo donde consideraba a Cristo Nuestro Señor en su trono de gloria con lo que sentía su espíritu muy regalado que no podía sino guardar silencio, porque si osaba hablar palabra algo interior le hacía fuerza de que callase". ${ }^{33}$ De hecho Cristo en majestad era el personaje central en las

31 Estaciones de Josefa de San Luis Beltrán. AGN, Inquisición, 1593, fol. 60 vta.

32 Testimonio de Pedro López de Covarrubias, México, 4 de abril de 1650. AGN, Inquisición, 432, fol. 473 r.

33 Testimonio de Nicolasa de Santo Domingo, México, 30 de julio de 1650. AGN, Inquisición, 433 , fol. 134 vta. 
visiones de Josefa y de María. Él era su principal interlocutor y su voz autorizada dirimía conflictos, amonestaba y aconsejaba. Él era el modelo de virtudes, el esposo a quien se dirigían sus diálogos amorosos y su máximo director espiritual. Él era quien solicitaba la participación de los asistentes a los coloquios y respondía sus dudas y peticiones. A él también se ofrecían prácticas como el Via crucis, que todos los viernes de Cuaresma Josefa guíaba cargando una cruz a cuestas y vestida con túnica negra, acompañada de su familia y de sus devotos.

Después de Cristo, el segundo personaje presente en las visiones era la Virgen María, sobre todo en su advocación de la Inmaculada Concepción. Acababan de pasar los conflictos teológicos alrededor del tema de la presencia o ausencia del pecado original en la persona de la madre de Cristo; en 1612, el rey de España había jurado a la Inmaculada como patrona del imperio, lo que ocasionó una serie de disputas entre maculistas e inmaculistas que tuvieron lugar en 1616 en Toledo y Alcalá. En 1619 una nueva declaración (ahora por parte del pontífice Paulo V) que favorecía a los inmaculistas provocó que los dominicos se enfrentaron a las otras órdenes en sermones y poemas durante una celebración en la ciudad de México. ${ }^{34} \mathrm{~A}$ causa de la virulencia que alcanzaron tales discusiones, Felipe III las prohibió y promovió que los universitarios hicieran la promesa de defender que la Virgen María había sido concebida sin la mancha del pecado original. Desde entonces el tema recibió un enorme impulso oficial que se reflejó hasta en las visiones místicas.

En ellas ocupaban también un lugar destacado los santos; en las Romero tenían un papel privilegiado los de la orden de Santo Domingo y los ángeles. Las hermanas mencionaban, junto con los conocidos arcángeles, algunos otros con nombres extravagantes. A María la atendía un ángel pelón llamado Alegría, a quien Brunón solicitaba opinión sobre sus escritos por medio de su dirigida. El de Josefa, de nombre Mansedumbre, olía a ámbar, intervenía continuamente en sus visiones, le detenía el vestido para evitar que se le levantara y con ello prevenir indecencias, la aconsejaba en la revisión de los escritos y la proveía de reliquias. Josefa decía además que ella podía ver a los ángeles de la guarda de las personas y llegó a asegurar que Joseph Bruñón poseía uno muy lindo y resplandeciente llamado Saltiel, uno de los siete arcángeles de la corte celestial. Ese arcángel le había asegurado que Vértiz tenía el don de conocer los espíritus. Teresa,

34 Jiménez Rueda, Julio: Herejías y supersticiones en Nueva España, México, 1946, págs. 229 y ss. 
bastante menos apegada a la ortodoxia que sus hermanas, declaró que tenía por ángel de la guarda al que lo había sido de Cristo.

Pero sin duda, el otro personaje que ocupó un espacio destacado en las visiones fue el Demonio; tanto así, que varios de los confesores comenzaron a sospechar que sus dirigidas estaban poseídas y llegaban para conjurarlo y hacerles exorcismos armados con estola, breviario y agua bendita. Fray Rodrigo de Medinilla, uno de esos exorcistas, llegó a declarar que había oído contar a una india cacica de Tepetlaoztoc que en su gentilidad este pueblo tenía muchos brujos y que, como las hermanas estuvieron mucho tiempo en él, aprendieron muchas artes demoniacas. Salieron además del pueblo aborrecidas por los indios, quienes las expulsaron por considerarlas gente que tenía pacto con el Demonio. Con todo, las reacciones de las muchachas no permitían aseverar que eran víctimas de posesión, pues, a los conjuros que duraban varias horas, ellas respondían con gran devoción, inclinando la cabeza y rezando..$^{35}$

La actitud de los confesores no era gratuita. Teresa decía que el Enemigo se le aparecía como un niño rubio que la aporreaba, la provocaba a acciones deshonestas y se le mostraba "con una cinta encarnada haciendo acciones como para que se ahorcase". ${ }^{36}$ En otra ocasión, Josefa anunció que su ángel le había señalado que tendría una lucha feroz con el Demonio en dos semanas. El día del encuentro, y ante un numeroso auditorio que acudió curioso a observar, la joven hizo aparecer gracias a la conjunción mágica de la palabra, la actuación y la imaginación, dragones y negros demonios con mazas en las manos; se arrastró por el suelo, mostró sus manos llenas de polvo quemado de azufre, se exhibió aporreada y desgreñada, acudió a la intercesión de San Francisco y de Santa Catarina, utilizó cordones y reliquias y se levantó en vilo con los pies hacia arriba. El Demonio finalmente se alejó cuando ella se aproximó a Joseph Bruñón, quien, además de elegido y conocedor de conciencias y milagros, se volvía también espantador de diablos. A pesar de su aparente debilidad, Josefa siempre salía triunfante en las luchas e incluso, en casa de Pedro López, arrojó a un demonio llamado Malveró que vivía en el frescor de una cobacha, y que al salir expulsado "al valle de Josafat" mató al gato doméstico. ${ }^{37}$

35 Testimonio de fray Rodrigo de Medinilla, México, 4 de junio de 1653. AGN, Inquisición, 432, fol. $211 \mathrm{r}$.

36 Testimonio de Teresa de Jesús, México, 11 de septiembre de 1649. AGN, Inquisición, 432, fol. 308 r. y s.

37 Testimonio de Pedro López de Covarrubias, México, 4 de abril de 1650. AGN, Inquisición, 432 , fol. 456 vta. 
En muchas de sus puestas en escena, las hermanas hacían uso de imágenes y reliquias de manera abundante. Las hermanas decían que no podían tener cerca imágenes porque sólo viéndolas se arrobaban. Josefa mandó fabricar a Pedro López de Covarrubias un retrato de la Virgen de Copacabana porque "es muy milagrosa". ${ }^{38}$ Ella misma también utilizaba a menudo una pequeña escultura de cera de Agnus Dei del niño Jesús que le prestaba el mismo Pedro López. La imagen tenía fama de milagrosa y había pertenecido a sor Isabel de Jesús (la monja de Santa Clara) y Josefa la usaba cuando estaba enferma, se lo ponía cerca del pecho y le decía lindezas. En una ocasión sacó al niño Dios de la cajita de plata y oro con vidriera en que estaba guardado, y lo alzó en alto como si fuera la hostia. Cuando lo bajo, después de un rato de arrobamiento, la imagen traía en la barriguita, encajada en el ombligo, una cuenta azul que regaló a don Joseph de Vértiz.

Esta materialización de objetos (piedras, pequeñas cruces, cuentas de rosario) fue bastante común y su fuente de inspiración proviene de la vida de la terciaria franciscana Juana de la Cruz (1481-1534) escrita por Antonio de Daza (impresa en Madrid en 1611 y 1614) y citada en varias ocasiones durante el juicio. Según su biógrafo, la venerable Juana "enviaba" esas cuentas al cielo donde eran bendecidas por el Padre Eterno y regresadas como remedio para múltiples enfermedades. En las ciudades de Nueva España circulaban varias de esas cuentas, según consta por algunos manuscritos recogidos por el Santo Oficio. ${ }^{39}$ De hecho la misma Teresa Romero decía que su cuenta de vidrio azul había sido "tocada a las de Santa Juana", y que a ella se la dio un religioso (seguramente franciscanos) de Texcoco. ${ }^{40}$

Al igual que las cuentas de "Santa Juana", los objetos que hacían aparecer las hermanas Romero eran considerados como reliquias por sus poseedores y sus gracias y cualidades curativas eran descritas con toda minucia por las "beatas" durante sus arrobos. María pretendía recibir pequeñas cuentas en la boca y decía que su ángel las bajaba del cielo y que eran las que había traído Jesús siendo niño atadas a su muñeca. Al igual que las cuentas de los rosarios de la terciaria Juana de la Cruz que circulaban en todo el imperio español, estas cuentas tenían poderes curativos. Teresa

38 Ibidem, fol. 464 vta. López mandó pintar la imagen a fray Diego Becerra.

39 AGN, Inquisición, v. 305, exp. 4; v. 467/1, exp. s/n, fs. 239 r y ss.; v. 471/1, exp. 64, fs. 221 r. y ss.; v. 478/2, exp. s/n, fs. 308 r. y ss.; v. 604/1, exp. 39, fs. 318 r. y s. Agradezco a Dorota Bieñko estos datos.

40 Los papeles del juicio de Teresa Romero están en AGN, Inquisición, 1499; son los únicos del caso que han sido publicados en el Boletín del Archivo General de la Nación, tomo XVII, México, 1946, pág. 400. 
repartió las astillas de un trozo del lignum crucis que arrojó también por la boca. Muchos de esos objetos, que a veces eran besados por las ánimas del purgatorio, los traían en el cuello sus devotos para protegerse de los males, del mismo modo que el padre Pocasangre les colocaba a sus sobrinas collares de reliquias para protegerlas del Demonio. María también hacía desaparecer camándulas (pequeños rosario de diez cuentas) arrojándolas sobre su cabeza; decía que su ángel las bendecía y las regresaba a sus devotos con mucha fragancia. Alguna vez, al terminar la consagración durante una misa celebrada por Vértiz, María aseguró haber visto cómo los purificadores y corporales utilizados se manchaban con el sudor y con la sangre de Cristo, por lo que debían ser guardados como reliquias. El prodigio, aseguraba, "sólo lo podían ver los que tenían abiertos los ojos del alma". Joseph Bruñón los conservó en una cajita de olinalá, aunque nunca pudo ver la sangre. ${ }^{41}$

Pero el culto a las reliquias tenía un límite. Cuando Josefa presentó las heridas de espinas en la frente, uno de los presentes, el secretario del consulado Diego Manuel de la Rocha, limpió la sangre de la frente con un paño, pero como la hemorragia era abundante muy pronto se juntaron muchos de ellos. Josefa mandó que todos fueran quemados, para que no hubiera peligro de que triunfara la soberbia. Agregó que "quien aspiraba a la perfección debía desnudarse de todo respeto mundano". ${ }^{42}$

La actitud de las jóvenes ante las creencias y las imágenes quedó resumida en el testimonio del padre Medinilla: "Y noté con singularidad admirado del orden, memoria y tesón que llevaba, no imaginable con la astucia de una mujer... Sin embargo los advertidos reparos del inquisidor Juan de Mañozca me avivaron el cuidado y la atención. Pero era tanta la máquina, que no me pareció el embuste de mujeres ignorantes y me incliné por la sola ilusión del Demonio... Mostraba a la imaginación los preciosos atributos con que solemniza la Iglesia a la Virgen y de una imagen que tengo de Cristo dijo que le parecía mucho, pero con gran diferencia en los ojos por ser los del señor de extraña variedad, hermosura y resplandor... No halle este estilo en su hermana Teresa cuyas palabras eran menos devotas y a veces usaba como glosa a lo divino el pie de una canción profana". ${ }^{43}$

41 Resumen de la causa de don Joseph Bruñon de Vértiz, sin fecha. AGN, Inquisición, 576, fol. 320 r. y ss.

42 Testimonio de Hernando de la Fuente, México, julio de 1650. AGN, Inquisición, 432, fol. 130 r. y ss.

43 Testimonio de fray Rodrigo de Medinilla, México, 4 de junio de 1653. AGN, Inquisición, 432, fol. 189 r. y vta. 


\section{Las denuncias y el final}

A pesar de su ortodoxia y de sus atractivos espectáculos, las hermanas Romero cayeron finalmente en las cárceles inquisitoriales el 9 de septiembre de 1649. Josefa y María tenían entonces veintinueve años, Nicolasa veintitrés y Teresa recién había cumplido los dieciocho. Con ellas fueron también encarcelados Joseph Bruñón de Vértiz, el clérigo de 39 años secretario de Josefa, y Diego Pinto, el marido de María. ${ }^{44}$ Aunque la Inquisición ya había recibido noticia de lo que pasaba en la familia Romero tres años atrás, pues a lo menos dos de sus funcionarios las visitaban, no comenzó a tomar cartas en el asunto sino hasta junio de 1649. Es cierto que una de las causas de la lenta actuación del tribunal en este caso fue la saturación burocrática provocada por el juicio contra los judíos portugueses, juicio que finalmente se desahogó en abril de ese año; con todo, la demora no puede ser explicada sólo por ese hecho. Todo hace pensar que el caso de las Romero no debió ser excepcional y que la existencia de tales prodigios era demasiado cotidiana como para que el tribunal le prestara una atención especial.

De hecho, las denuncias no aparecieron en un principio, ni siquiera por parte de los sacerdotes desilusionados ante el poco caso que las "beatas" hacían de sus consejos. Muchos de ellos sencillamente las tacharon de ilusas "arrepticias" sin maldad, y se alejaron sin mayor escándalo, incluso aquellos que sin éxito intentaron exorcizarlas. Según cuentan varios testigos, el caso no se prestó más que para algunos comentarios sarcásticos en las tertulias conventuales. Actitudes similares hacia las hermanas tuvieron también los laicos. Los primeros que se distanciaron de ellas fueron Francisco Antonio de Loaysa y su mujer Ana de la Parra. Ella, por el disgusto que le causó que su marido les regalara su ropa y sus joyas; él, por los comentarios que le hizo Teresa durante su estancia en su casa sobre las falacias que utilizaba su hermana Josefa para engañar a sus seguidores. A partir de ahí, el cerero comenzó a desacreditar a la visionaria quien, en venganza, denunció en uno de los arrobos que entre sus celadores seglares había un Judas llamado Francisco Antonio. ${ }^{45}$

44 Diego Pinto participó en la fuga de Guillén de Lampart, pero ambos fueron apresados de nuevo. El marido de María de la Encarnación murió en las cárceles inquisitoriales antes de alcanzar sentencia.

45 Testimonio de Ana de la Parra, México, 14 de julio de 1650. AGN, Inquisición, 432, f. 228 vta. 
No fue tampoco una causa menor para el paulatino alejamiento de sus devotos el embarazo de Teresa y las actitudes cada vez más altaneras de Josefa con sus confesores (sobre todo con los dominicos Medinilla y Fonseca) y el conflicto con la monja Isabel de Jesús. En sus raptos de ese periodo la joven visionaria equiparaba sus propios sufrimientos con los de Cristo, abandonado por sus discípulos. Influyeron también en esa deserción la muerte de Juan Romero, asesor y apoyo de sus hijas y las noticias de que el Santo Oficio estaba tomando cartas en el asunto. Pero la gota que derramó el vaso fue la presencia de un asunto amoroso.

De entre todos sus seguidores Josefa tenía una especial predilección por Joseph Bruñón de Vértiz. En sus raptos su voz, disfrazada con la de Cristo, siempre hacía referencias a él llamándolo "tu amigo"; con esa misma voz le había mostrado su preferencia al nombrarlo escribano de sus arrobos. El joven, que había encontrado en esta elección "divina" la razón de su existencia, se entregó de lleno a esa mujer a quien consideraba intermediaria de la voluntad de Dios. Ella, sin embargo, lo veía con un afecto mucho más humano, afecto que con el paso del tiempo, con el abandono de sus otros devotos y con la muerte de su padre, se volvió una pasión desesperada. En uno de sus últimos raptos, en la primavera de 1649, Josefa tomó a Bruñón de la ropa "por los pechos" y restregó el cuerpo contra el suyo; el joven clérigo la alejó aterrado. ${ }^{46}$

Bruñón no volvió más a la casa del barrio de Santa Catalina. Poco después, Josefa supo que su amigo se había ido a refugiar con su hermana María en las huertas del marqués. Desde hacía varios meses la gemela, quien también estaba teniendo visiones por entonces, había sido visitada por Vértiz, enviado por Josefa para convencerla de dejar sus raptos. El joven clérigo, recién ordenado sacerdote, encontró en María los mismos satisfactores espirituales que le daba Josefa, sin los peligros carnales, pues su nueva guía estaba casada y vivía con su marido. Ahí comenzó a expresar que Dios le había traído a estas partes para explicar las epístolas de San Pablo y completar lo que él no había explicado en materia de los espíritus y los raptos. Llena de celos y desesperación, Josefa envió a las huertas del marqués al que entonces era su confesor, el jesuita Bartolomé Castaño; a él le había insinuado que su hermana fingía sus raptos. El sacerdote tuvo varias entrevistas con María y con Vértiz y, ante las evidencias de

46 Testimonio de Joseph Bruñón de Vértiz, 7 de octubre de 1649. AGN, Inquisición, 432, fol. 359 r. y s. El proceso de Bruñón se encuentra en el volumen 443, pero también existen resúmenes de sus escritos y de su juicio en los números 436, 503 y 576. 
los engaños de la primera y de la heterodoxia mística del segundo, llevó el caso ante el tribunal del Santo Oficio.

En el proceso de las hermanas Romero se hizo evidente lo que Diana Ceballos califica como "el camino que conectaba la sociedad con las instituciones": "A falta de un sistema de policía tal y como lo conocemos en la actualidad, con agentes que supervisen el mantenimiento del orden, en el Antiguo Régimen, la sociedad entera ejerce esas funciones de policía, de control y de disciplina, a través de mecanismos como la delación, la acusación y el rumor... En una sociedad de palabras, el rumor, lo que se dice y se tiene por general, posee carácter de verdad". ${ }^{47}$ El éxito de las hermanas Romero había dependido en buena medida de esa cultura oral que expandía y trasmitía anécdotas y sucesos, pero esa misma cultura fue la causa de su ruina al hacer públicos sus conflictos privados y al convertir una "voz y fama de santidad" en una acusación de "diabólico artificio y de extrema insolencia". ${ }^{48}$

Durante el proceso, las hermanas "confesaron" sus engaños, dijeron que habían obrado sin conciencia de maldad; pero el juicio fue tan prolongado que dos de ellas, María y Josefa, murieron en la cárcel, al igual que Diego Pinto. Nicolasa fue penitenciada en 29 de octubre de 1656 y salió libre; Martín de Guijo da de ella esta escueta noticia: "fue condenada a doscientos azotes; no se los dieron porque intercedió la virreina por ser doncella" ${ }^{49}$ Teresa fue liberada en 1659 junto con su hijo, un niño de diez años al que había dado a luz recién llegada a la cárcel. Salió en el auto de fe del 19 de noviembre, cuando fue quemado en la hoguera Guillén de Lampart; ese mismo día ardían también los restos mortales de Joseph Bruñón de Vértiz, quien había muerto en la cárcel en 1656 emitiendo blasfemias y completamente loco. Teresa fue condenada a 200 azotes (que le fueron condonados) y a servir por diez años en el hospital de la Concepción. Su hijo la acompañó también a cumplir su sentencia. Durante su estancia en la cárcel, Teresa le había enseñado a leer y a escribir en una cartilla que le facilitaron los inquisidores; esto fue lo único que le dejó como herencia al morir en el hospital..$^{50}$

47 Gómez, Diana Ceballos: "Gobernar las Indias", Ius Commune, Frankfurt, Vittorio Klostermann, 1998, v. XV, págs. 181-218: 209 y 214.

48 Testimonio de fray Rodrigo de Medinilla, México, 4 de junio de 1653. AGN, Inquisición, 432, fol. 205 vta.

49 De Guijo, Diario..., v. II, pág. 67.

50 AGN, Inquisición, 1499; son los únicos del caso que han sido publicados en el Boletín del Archivo General de la Nación, tomo XVII, México, 1946. 


\section{Conclusiones}

El caso de las hermanas Romero, como el de muchas de las "beatas" aparecidas en la era barroca en España e Hispanoamérica, es ideal para entender los mecanismos comunicativos de una sociedad oral. Un fenómeno como éste sólo es posible en una comunidad de creyentes que comparten los mismos códigos y cuyos esquemas mentales se basan en la credulidad, en el "lugar común" y en otros recursos retóricos, en el carisma de los emisores de discursos, en la utilización de imágenes visuales y textuales, de objetos y reliquias. En una sociedad así, donde la reflexión especulativa propia de la ciencia no existe aún y las palabras y las cosas forman parte de un universo sin fisuras, es posible que el discurso y las prácticas (el saber y el hacer) sean indisociables. Con todo, el dictamen final del tribunal del Santo Oficio nos muestra una ruptura, aquella que Michel de Certeau ha calificado como "lugar inestable" en la modernidad; sin haber desechado la posibilidad de lo prodigioso divino o demoníaco, la cultura barroca ha introducido una tercera categoría "humana" para explicar esos fenómenos: el engaño. En ese mundo, en el que la verdad y la mentira se han conformado como categorías estructuradoras de la realidad, existe cabida para incluir a la imaginación, esa facultad que puede llevarnos al engaño pues, según dice fray Luis de Granada, "es una de las potencias de nuestra ánima que más desmandadas quedaron por el pecado y menos sujetas a la razón. De donde nace que muchas veces se nos va de casa, como esclavo fugitivo, sin licencia; y primero ha dado una vuelta al mundo, que echemos de ver a donde está. Es también una potencia muy apetitosa y codiciosa de pensar todo cuanto se le pone delante, a manera de los perros golosos, que todo lo andan probando. Es también una potencia muy libre muy certera, como una bestia salvaje, que anda de otero, sin querer sufrir sueltas, ni cabestro, ni dueño que la gobierne". 